\title{
Comparative study of environmental regulations in Latin America
}

\author{
G. Rincón ${ }^{1,2}$, L. Cremades ${ }^{2}$, U. Ehrmann ${ }^{1}$ \& A. Peña ${ }^{1}$ \\ ${ }^{1}$ Universidad Simón Bolivar, Dpto. Procesos y Sistemas, Venezuela \\ ${ }^{2}$ Universitat Politècnica de Catalunya, Spain
}

\begin{abstract}
Air quality regulations describe the quality level enforced by the regulating authority. These regulations have been established as an attempt to reduce and control the negative impact of air pollution upon the environment and human health. They are based upon the concentration levels of pollutants that are considered non-hazardous for each individual, including the more vulnerable population like children and the elderly. This study presents an analysis of current environmental regulations for permitted PTS, $\mathrm{PM}_{10}, \mathrm{PM}_{2.5}, \mathrm{CO}, \mathrm{NO}_{2}$, $\mathrm{SO}_{2}$, and $\mathrm{O}_{3}$ concentration levels in thirteen Latin-American countries (LACs), and their comparison with similar regulations established by the United States Environmental Protection Agency (US EPA) and the World Health Organization (WHO). Most LACs reproduce US EPA standards, regardless of their specific regional circumstances; however, they do not update these standards at the frequency the US EPA does. Few regulations follow WHO recommendations. Concerns are raised regarding LACs capabilities to effectively monitor air quality and enforce compliance.
\end{abstract}

Keywords: air quality, Latin American standard regulations, WHO, US EPA, criteria pollutants, compliance.

\section{Introduction}

Air Quality regulations describe the maximum allowed pollution levels enforced by the regulating authority [1]. The upper threshold values established by the standard regulations correspond to those limits below which no harmful effects due to air pollution are expected. The aim of these regulations is to protect the citizens' health. 
While designing regulations, local factors such as race related health risk, available technologies, social factors, economics, degree of development, capability to implement these regulations and control compliance, should ideally be considered [2]. This implies that each country should establish its own regulations, based on internationally accepted health risk studies, but adapted to local factors and circumstances revealed through site specific scientific and epidemiological evidence.

In most of the developed world, environmental regulations are revised periodically in response to new scientific evidence and feedback experiences. Also, there is a general awareness among citizens, actual air quality information can be easily accessed, and has become an issue of public interest.

The objective of the present study is to compare air quality regulations in force among Latin American Countries (LACs). Issues such as site specificity, local health risk assessment, revision periods and comparison with air quality standards in force in developed countries will be addressed.

For this purpose, we analyzed the air quality regulations of thirteen LACs, and compared them with each other, and with those regulations recommended by the World Health Organization (WHO) in their Air Quality Guidelines (AQGs) [2], and those established by United States Environmental Protection Agency (US EPA) in their National Ambient Air Quality Standards (NAAQS) [3].

\section{Scope of the study}

In the present study, six from the seven US EPA NAAQS criteria pollutants were considered; that is, particulate matter with an aerodynamic diameter less than or equal to 10 microns $\left(\mathrm{PM}_{10}\right)$, particulate matter with a diameter less than or equal to 2.5 microns $\left(\mathrm{PM}_{2.5}\right)$, carbon monoxide $(\mathrm{CO})$, nitrogen dioxide $\left(\mathrm{NO}_{2}\right)$, ozone $\left(\mathrm{O}_{3}\right)$, and sulfur oxides $\left(\mathrm{SO}_{\mathrm{x}}\right)$. In addition, total suspended particles (TSP) were included because most LACs regulate their concentration. For each contaminant, the two most frequently regulated averaging periods (AP) were considered.

\section{Description and impact of each pollutant}

\subsection{Particulate matter}

Particulate matter (PM) is the term used for any substance, except water, that is suspended in the atmosphere as solid particles or liquid droplets under normal conditions. Their size is microscopic, but above molecular dimensions. These particles originate from diverse sources such as mechanical disruption processes (crushing, grinding, abrasion), power plants, industrial processes, and diesel trucks, and may be formed in the atmosphere by transformation of gaseous emissions. According to their size, PM is classified into PTS, PM $_{10}$ (coarse particles) and $\mathrm{PM}_{2.5}$ (fine particles).

Several epidemiological studies have linked PM with premature mortality, respiratory diseases, respiratory emergencies, and lung cancer [4-6]. PM enters 
the respiratory system by inhalation. There, $\mathrm{PM}_{10}$ deposits in the upper respiratory tract, while $\mathrm{PM}_{2.5}$ is capable to penetrate the alveolar region. Because $\mathrm{PM}_{2,5}$ penetrates deeper into the lungs and its composition includes more toxic substances, these particles pose a much higher health risk than the $\mathrm{PM}_{10}$. Therefore, the WHO and US EPA establish more stringent maximum allowed limits for $\mathrm{PM}_{2.5}$.

The averaging period (AP) considered in this study for TSP, $\mathrm{PM}_{10}$ and $\mathrm{PM}_{2.5}$ correspond to 24 hours and annual arithmetic mean. Those are also the APs established by the US EPA and WHO regulations for PM10 and $\mathrm{PM}_{2.5}$.

\subsection{Carbon Monoxide}

Carbon monoxide $(\mathrm{CO})$ is a colorless, odorless and poisonous gas produced by incomplete burning of carbon in fuels. When $\mathrm{CO}$ enters the bloodstream, it reduces the delivery of oxygen to the body's organs and tissues. Health threats are most serious for those who suffer from cardiovascular disease, particularly those with angina or peripheral vascular disease. Exposure to elevated CO levels can cause impairment of visual perception, manual dexterity, learning ability and performance of complex tasks.

APs considered for $\mathrm{CO}$ in this study are 8 hours and 1 hour, similarly to US EPA and WHO.

\subsection{Nitrogen Dioxide}

Combustion processes generate $\mathrm{NO}$ as sub-products. In the troposphere, NO rapidly oxidizes to $\mathrm{NO}_{2}$, which is toxic at concentration levels above $200 \mu \mathrm{g} / \mathrm{m}^{3}$. In the presence of hydrocarbons, $\mathrm{NO}_{2}$ initiates free radical chain reactions that produce tropospheric ozone and nitrite aerosols, which contribute to PM2.5 and photochemical smog [2].

APs considered for $\mathrm{NO}_{2}$ throughout this study are the same recommended by the WHO (1 hour and annual mean) whereas US EPA only considers the annual arithmetic mean.

\subsection{Sulfur Dioxide}

Like $\mathrm{NO}_{2}, \mathrm{SO}_{2}$ results from combustion processes; in this case, they originate from sulfur compounds present in fossil fuels. Therefore, atmospheric $\mathrm{SO}_{2}$ concentration levels are higher in those countries where fuel sulfur content is not regulated. Besides being toxic by itself, $\mathrm{SO}_{2}$ produces sulfate particles in the atmosphere. Chronic $\mathrm{SO}_{2}$ and sulfate particle exposure correlates with increased premature mortality due to respiratory and cardiovascular diseases [7].

APs considered in this study are similar to those regulated by US EPA; that is, 24 hours and annual mean. Due to its acute toxicity, WHO recommends $\mathrm{SO}_{2}$ APs of 10 minutes and 24 hours.

\subsection{Ozone}

Ozone is a secondary pollutant that results from sunlight induced photochemical chain reactions of nitrogen oxides $\left(\mathrm{NO}_{\mathrm{x}}\right)$ and volatile organic compounds 
(VOCs). Ozone is a powerful oxidant that causes severe respiratory tract irritations. Several studies have revealed associations between $\mathrm{O}_{3}$ and hospital admissions or emergency visits for respiratory conditions, diminished lung function, and more recently, acute effects on mortality in large cities [8].

Again APs considered in this study coincide with those established by US EPA (1-h and 8-h); while WHO only suggests APs of 8 hours.

\subsection{Sample of Latin-American Countries (LACs) studied}

Among the twenty-two Latin-American countries, a sample of thirteen was selected. These are Mexico, Brazil, and Chile [9-11] which have highly polluted mega cities; El Salvador, Costa Rica, Nicaragua and Panama [12-15] which are small Central American countries, but their capital cities exhibit significant air pollution; and Argentina, Bolivia, Colombia, Ecuador, Peru and Venezuela [1621], six South American countries with no significant air pollution problems reported. For comparative purposes, US EPA's NAAQS and WHO's AQGs were selected as reference standards.

It is necessary to point out that all the information regarding LAC, US EPA and WHO air quality regulations was obtained from official government Web sites [12-21].

\section{Latin American air quality regulations}

Following, each contaminant considered in this study is discussed in a separate section. Comparisons of the maximum allowed concentration levels for each contaminant are represented in bar graphs, with US EPA and WHO reference values displayed as horizontal lines. Empty spots for a given country in the bar graphs indicate that the particular pollutant and/or AP are not regulated in that country.

\subsection{Particulate matter}

In spite of the fact that US EPA's NAAQS, based upon epidemiologic evidences, since 1987 no longer regulate TSP but $\mathrm{PM}_{10}$, and discriminate between $\mathrm{PM}_{10}$ and $\mathrm{PM}_{2.5}$ since 1997, most LAC still regulate TSP regardless of their size, and without taking into consideration the severe health risks associated with the smaller particles.

Figure 1 displays the TSP for 24 hour and annual mean APs. It reveals that regulations for most countries are similar for both APs. With the exception of Colombia and Panama, all 24 hour standards correspond to values between 240 and $260 \mu \mathrm{g} / \mathrm{m}^{3}$, and all annual mean standards correspond to values between 75 and $80 \mu \mathrm{g} / \mathrm{m}^{3}$. Colombia has less stringent regulations whereas Panama has more stringent regulations. Argentinean air quality regulations do consider an AP of one month for TSP $\left(150 \mu \mathrm{g} / \mathrm{m}^{3}\right)$, instead of 24-h and annual mean APs. Chile and Peru are the only LAC in the sample that do not regulate TSP anymore.

On the other hand, five out of the thirteen LAC do not regulate $\mathrm{PM}_{10}$, (Argentina, Colombia, Ecuador, Venezuela, and Panama), ignoring the relatively 
increased health risk of the smaller particles. Argentinean and Colombian air quality regulations have last been updated before US EPA began to differentiate between TSP and $\mathrm{PM}_{10}$ (1973 and 1982 respectively;) amazingly, these countries have not revised their regulations more recently to include particulate matter discrimination according to its size. Even more surprisingly, the other three countries, whose last air quality revisions occurred after 1987 (Ecuador, 1999; Venezuela, 1995 and Panama, 1998), neither included particle size considerations in their regulations.

It is important to point out that since the late 1980s is well known that the health risk associated with TSP is not relevant in comparison with the risk associated with the smaller particles $\left(\mathrm{PM}_{10}\right.$ and $\mathrm{PM}_{2.5)}$. Therefore, neither US EPA nor WHO regulate TSP anymore; whereas $\mathrm{PM}_{10}$ and specially $\mathrm{PM}_{2.5}$ are so harmful that, until 2005, the WHO AQGs considered that there was no safe upper threshold.

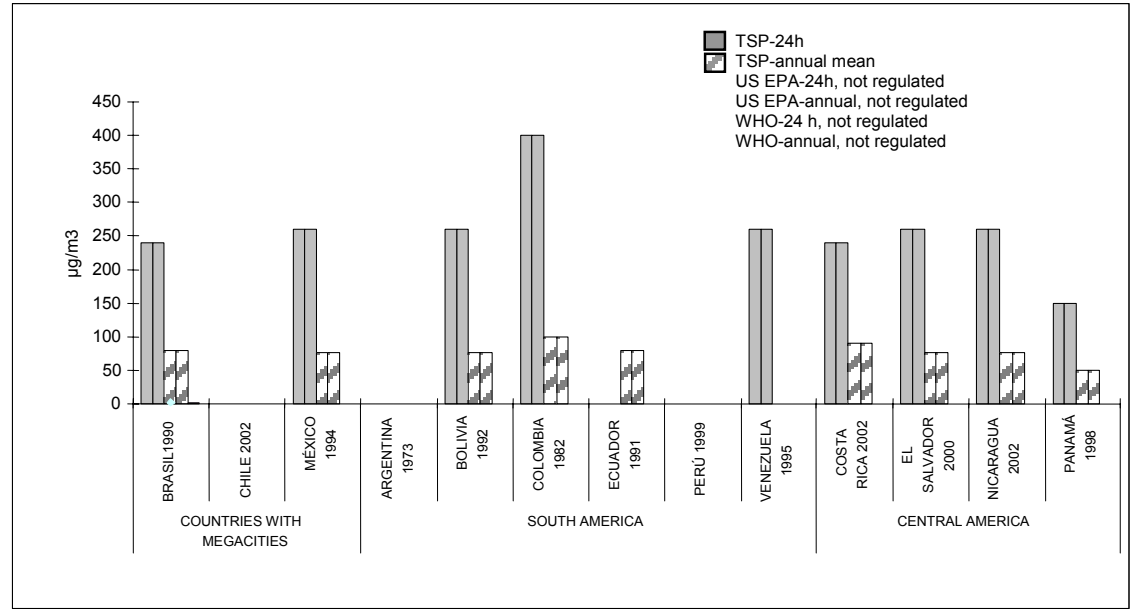

Figure 1: TSP-24h and TSP-annual regulations.

Figure 2 reveals that eight of the LAC studied regulates $\mathrm{PM}_{10}$ for $24-\mathrm{h}$ AP and seven additionally regulate the annual mean. All 24-h regulations establish the same upper threshold value than US EPA since 1987. Similarly, six of the LAC establishes the same upper threshold value for the annual mean than US EPA used to until 2006. Only Costa Rica sets a higher upper limit value. Interestingly, Chilean $\mathrm{PM}_{10}$ regulations, in force since 2002, coincide completely with US EPA's 2006 revision.

Regarding $\mathrm{PM}_{2.5}$, only El Salvador has regulated this pollutant since 2000. The upper threshold values are similar to those established by US EPA since 1997 until $2006\left(65 \mu \mathrm{g} / \mathrm{m}^{3}\right.$ and $\left.15 \mu \mathrm{g} / \mathrm{m}^{3}\right)$. El Salvador is a very small Central American country with high population density, high degree of deforestation, and many obsolete vehicles with no emission control. Actual WHO recommended values are more stringent than US EPA standards. 


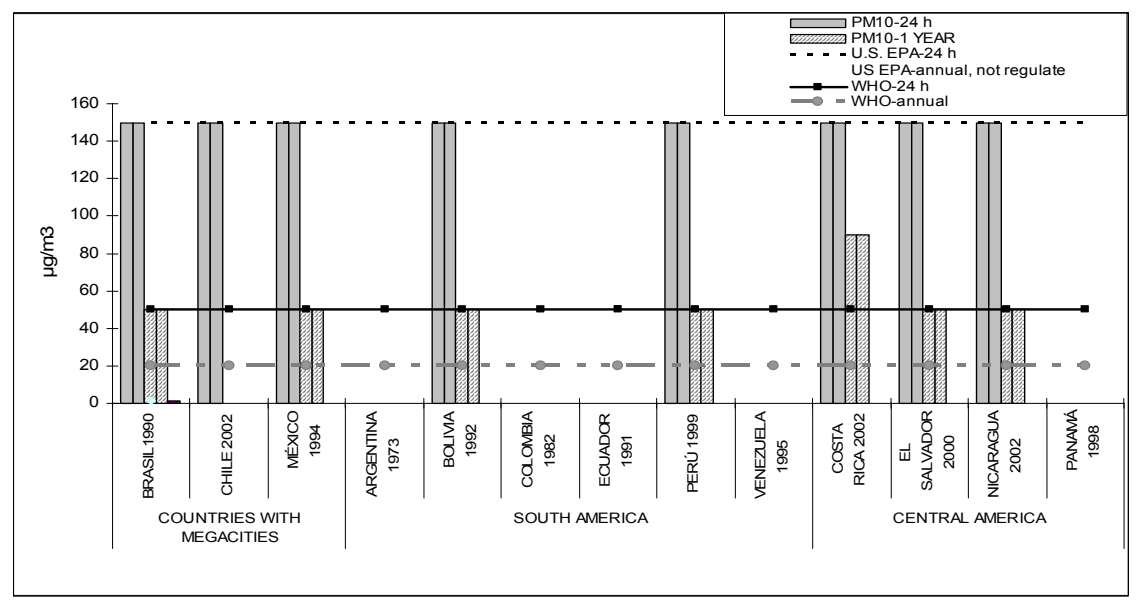

Figure 2: $\quad \mathrm{PM}_{10}-24 \mathrm{~h}$ and $\mathrm{PM}_{10}$-annual mean regulations.

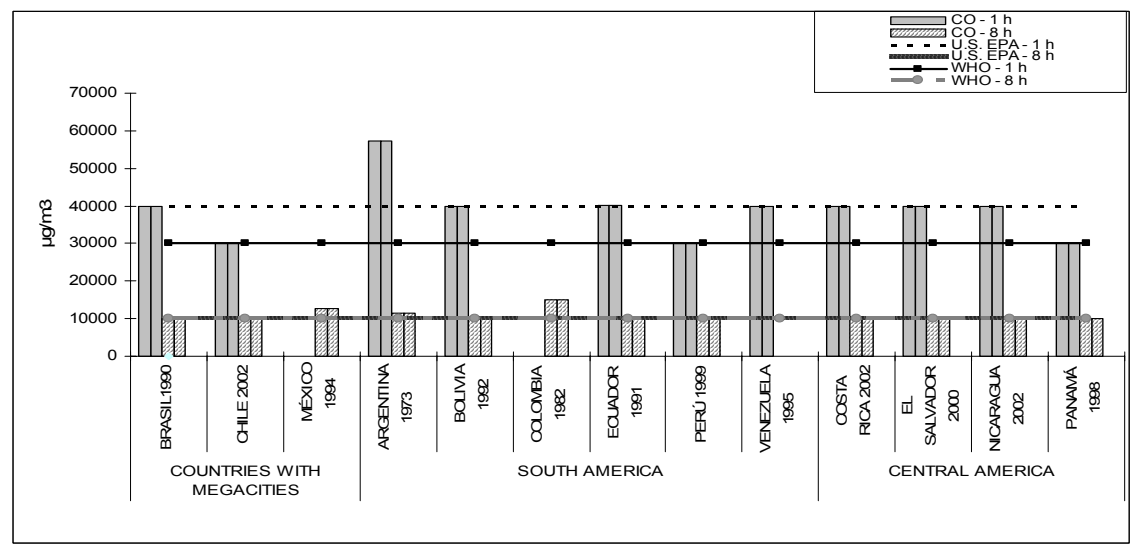

Figure 3: $\quad \mathrm{CO}-1 \mathrm{~h}$ and $\mathrm{CO}-8 \mathrm{~h}$ regulations.

\subsection{Carbon monoxide}

Figure 3 compares $\mathrm{CO}$ regulations for 1 hour and 8 hour APs. It shows that twelve of the LACs regulate this pollutant. For 1-h AP, seven of these countries establish the same upper threshold limits than US EPA $\left(40 \mathrm{mg} / \mathrm{m}^{3}\right)$, three of them establish the more stringent WHO recommended limits $\left(30 \mathrm{mg} / \mathrm{m}^{3}\right)$, while once again, Argentina permits much higher concentrations; perhaps because this country has not revised their air quality standards since 1973. Neither Mexico nor Colombia regulate 1-h atmospheric $\mathrm{CO}$ concentrations.

Regarding APs of 8-h, maximum allowed CO limits of US EPA AAQS, WHO AGGs and most LACs that regulate this pollutant, are similar $\left(10 \mathrm{mg} / \mathrm{m}^{3}\right)$. Mexico and Colombia allow slightly higher 8-h CO concentrations, while Venezuela does not regulate $\mathrm{CO}$ for 8-h AP. 


\subsection{Nitrogen dioxide}

Figure 4 shows that all LACs in the sample have some kind of $\mathrm{NO}_{2}$ regulations (Venezuelan regulations are not displayed in figure 4 because they only consider 24-h APs). Mexico, Argentina and Bolivia only consider 1 hour APs, Colombia, Ecuador, El Salvador and Panama consider only annual mean concentrations (similarly to US EPA), and Brazil, Chile, Peru, Costa Rica, and Nicaragua regulate both, 1 hour and annual mean APs.

Except for Peru, all upper $\mathrm{NO}_{2}$ limits for 1 hour AP are well above WHO recommended guidelines (320-400 vs $\left.200 \mu \mathrm{g} / \mathrm{m}^{3}\right)$. US EPA standards, usually more flexible than WHO's guidelines, do not include 1-h AP. Once again, Argentina stands out for its flexible regulations.

All LACs that regulate annual mean AP for $\mathrm{NO}_{2}$ use the same standard than US EPA, which is more than twice the WHO AQG recommended limit.

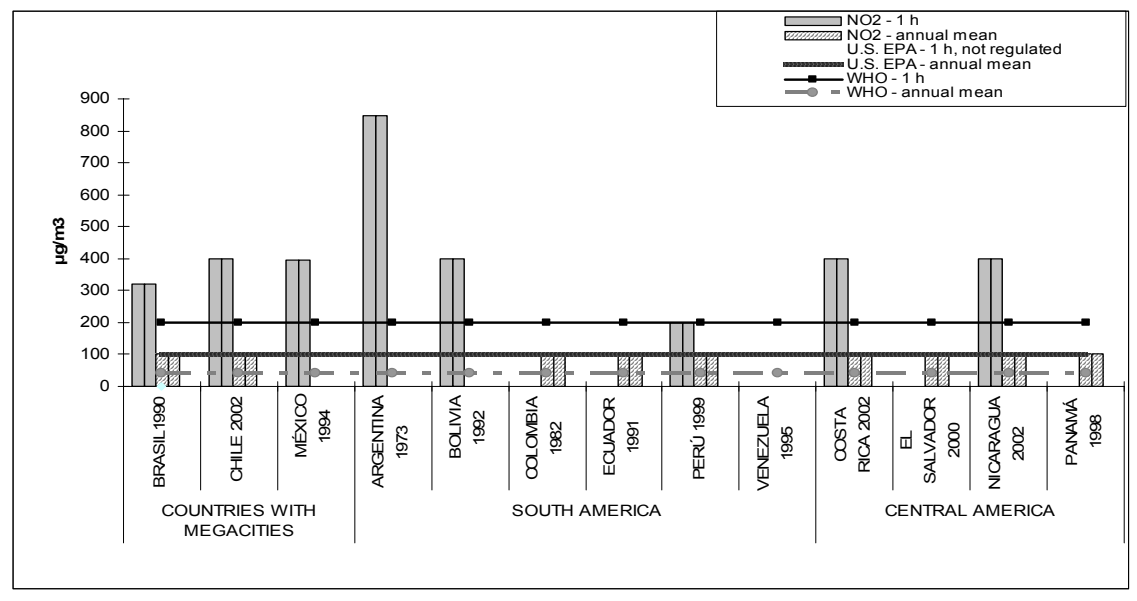

Figure 4: $\quad \mathrm{NO}_{2}-1 \mathrm{~h}$ and $\mathrm{NO}_{2}$ annual mean regulations.

\subsection{Sulphur dioxide}

In spite of studies that evidence severe acute $\mathrm{SO}_{2}$ toxicity over short time periods (10 min), neither US EPA nor any of the LACs in the sample regulate this pollutant for similar APs. WHO recommends upper threshold values of $500 \mu \mathrm{g} / \mathrm{m}^{3}$ for a 10 minute AP. Figure 5 reveals that all LACs except Argentina regulate atmospheric $\mathrm{SO}_{2}$ concentration either for 24-h AP, annual mean AP, or both. Argentina does not show standard values in figure 5, because its regulated AP is one month $\left(150 \mu \mathrm{g} / \mathrm{m}^{3}\right)$. All permitted annual $\mathrm{SO}_{2}$ concentrations are similar, and coincide with US EPA $\left(80 \mu \mathrm{g} / \mathrm{m}^{3}\right)$. For a 24-hour AP, most standards are also similar to those established by the US EPA $\left(\sim 365 \mu \mathrm{g} / \mathrm{m}^{3}\right)$. Chile and Mexico have slightly more strict regulations. It is worth noting that $2005 \mathrm{WHO}$ recommend $\mathrm{SO}_{2}$ concentrations limits are approximately 18 times lower than the US EPA limits. 


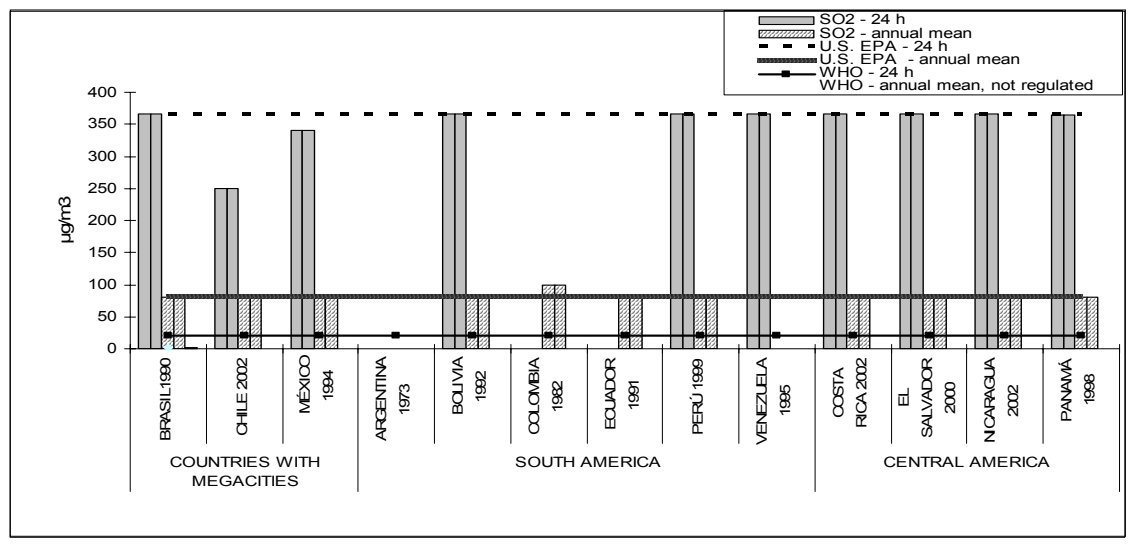

Figure 5: $\quad \mathrm{SO}_{2}-24 \mathrm{~h}$ and $\mathrm{SO}_{2}$ annual mean regulations.

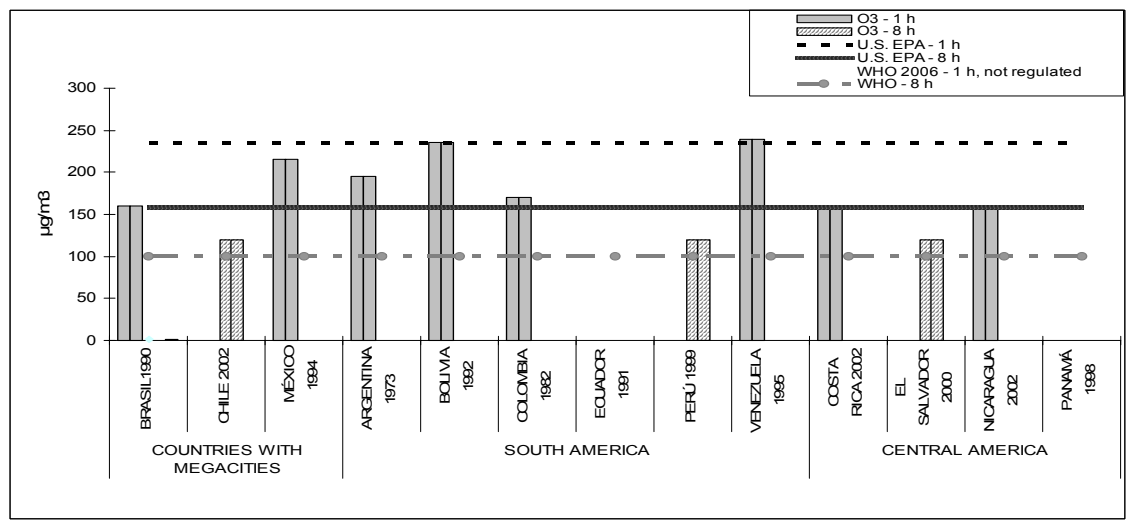

Figure 6: $\quad \mathrm{O}_{3}-1 \mathrm{~h}$ and $\mathrm{O}_{3}-8 \mathrm{~h}$ regulations.

\subsection{Ozone}

Figure 6 shows that overall, $\mathrm{O}_{3}$ regulations among LACs are the least uniform of all criteria pollutants. Most LACs regulate $\mathrm{O}_{3}$ for a 1 hour AP. Except for Bolivia and Venezuela, their standards, including Argentina, are more stringent than the US EPA standards. WHO does not regulate this AP.

Only three countries consider 8 hour APs (Chile, Peru, El Salvador). Surprisingly, their standards are similar the WHO recommended AQS value $\left(100 \mu \mathrm{g} / \mathrm{m}^{3}\right)$, and significantly lower than the upper limit value established by the US EPA $\left(157 \mu \mathrm{g} / \mathrm{m}^{3}\right)$.

\section{Examination and compliance}

The success of environmental regulations depends on the regulating agent's capability to enforce their compliance. In this study, we tried to locate in the 
Web public information regarding criteria pollutant concentrations of the LACs studied. These type of reports are easily available for developed countries. For example, Web AirNow continuously displays actual air quality indexes for major US cities [22]. On the contrary, similar reports for the LACs were not easily available. Up to our knowledge, only Mexico, Brazil and Chile publish continuously updated reports that reveal effective air quality control programs.

For the remaining LACs no similar information was located in the Web, which indicates that, in best of circumstances, this information is not easily accessible by the LAC's citizens. Scarce public information regarding LAC air quality raises concerns about their monitoring and control programs, and consequently their compliance.

\section{Final remarks}

By far, most LAC air quality regulations reproduce those US EPA standards in force at the time the countries design their own regulations, regardless of site specific factors, regional epidemiologic studies, or capability to control compliance.

Only in a few cases, WHO guidelines are considered; even though this is the organization that cares for human health worldwide, and is constituted by members of all nations, including those LACs studied herein.

Moreover, environmental regulations do not seem to be subjected to regular revision periods since most regulations have not been updated in more than 5 years. That is, they reproduce US EPA standards, but they do not actualize them according to US EPA AAQS or to proper scientific evidence. Consequently, maximum allowed pollutant concentrations are not adjusted adequately to protect public health. For instance, failure to regulate $\mathrm{PM}_{10}$ and $\mathrm{PM}_{2.5}$ instead of TSP reveal little concern for timely updates to ensure public health.

It is worth to note that most LACs are developing countries that lack of wellorganized administrative systems capable to pursue efficient air quality control programs and thus, ensure compliance. Indeed, only the most industrially countries exhibit evidence of systematic air quality control. No regulation will protect human health if its compliance is not ensured. Since air pollution has global impact, efforts to develop effective regional surveillance systems should be international.

\section{References}

[1] World Heath Organization. Guidelines for Air Quality: WHO/SDE/OEH/ 00.02.2000.

[2] World Heath Organization. Guidelines for Air Quality for particulate matter, ozone, nitrogen, nitrogen dioxide and sulphur dioxide: WHO/SDE/ PHE/06.02.2005.

[3] US Environmental Protection Agency. National Ambient Air Quality Standards, 2006. 
[4] Ostro B. \& Chestnut L., Assessing the Health Benefits of Reducing Particulate Matter Air Pollution in the United States, Environmental Research, Section A, 76, pp. 94-106,1998.

[5] Dockery D.W., Pope, C., Xu X., Spengler J., Ware J., Fay M., Ferris B. \& Speizer F., An Association between Air Pollution and Mortality in Six US Cities The New England Journal of Medicine, 329(24), pp.1753-1759, 1993.

[6] Pope C.A., Schwartz J. \& Ramsom M.R., Daily mortality and PM10 pollution in Utah Valley. Arch Environ Health, 47(3), pp. 211-217, 1992.

[7] Sánchez J., Romieu I., Ruiz S., Pino P. \& Gutierrez M., Efectos agudos de las partículas respirables y del dióxido de azufre sobre la salud respiratoria en niños del área industrial de Puchuncaví, Chile. Rev Panam Salud Publica/Pan Am J Public Health, 6(6), pp.384-391, 1999.

[8] Knowlton, K.; Rosenthal, J. E.; Hogrefe, C.; Lynn, B.; Gaffin, S.; Goldberg, R.; Rosenzweig, C.; Civerolo, K.; Ku, J. and Kinney P. L. Assessing Ozone-Related Health Impacts under a Changing Climate. Environ Health Perspect, 112(15), pp.1557-1563, 2004.

[9] Normativa Oficial Mexicana, NOM-020-021-022-023-024-025- SSA11993, 18/08/94.

[10] Consejo Nacional de Medio Ambiente (CONAMA) $\mathrm{N}^{\mathrm{o}}$ 3, Valores Nacionales de la Calidad del Aire, Brasil. 28/06/90.

[11] Diario Oficial de La República de Chile $\mathrm{N}^{\mathrm{o}}$ 110, 112, 113, 114, 115, 59(98, Norma Primaria de la Calidad del Aire, 06/08/02.

[12] Casa Presidencial de El Salvador, Norma de Calidad de Aire Ambiente, $31 / 05 / 2000$.

[13] Gaceta Oficial de Costa Rica. Na 30221-S, Artículo 5, 21/03/2002.

[14] República de Nicaragua, NTON 05 012-02, Nª 5, Límites Máximos de Inmisión de Contaminantes en el Aire, 2002.

[15] Gaceta Oficial de Panamá, Decreto $N^{\circ} 158$, Normas de Calidad del Aire Ambiente, 1998.

[16] Ley Nacional 20.284 "Contaminación atmosférica", Buenos Aires 16/04/1973, Boletín Oficial 03/05/1973.

[17] Ley de Medio Ambiente 1333, 27 de abril 1992, Gaceta Oficial de Bolivia, 15/07/1992.

[18] Ministerio de Salud, Niveles de Contaminantes del Aire, Colombia. 1982.

[19] Registro Oficial No 726, Reglamento de las Normas de Calidad del Aire, Ecuador,15/07/1991.

[20] Comisión Nacional del Ambiente (CONAM), Estándares Nacionales de la Calidad del Aire, Perú, 1999.

[21] Decreto 638. "Norma sobre calidad del aire y control de la contaminación atmosférica". Gaceta Oficial de Rep. Venezuela, Número 4899, Mayo, 1995.

[22] AirNow, http://airnow.gov/ February 2007 